\title{
Aplikasi 1-Methylcyclopropeneuntuk Meningkatkan Vase life Bunga Potong Tapeinochilos anannaceae K. Schum
}

\author{
Aplication 1-Methylcyclopropeneto Increase the Vase Life of Cut Flower \\ Tapeinochilos anannaceae K. Schum
}

\author{
Ilsa Salsabilla*, Juang Gema Kartika
}

\begin{abstract}
${ }^{1}$ Departemen Agronomi dan Hortikultura, Fakultas Pertanian, Institut Pertanian Bogor (Bogor Agricultural University), J1. Meranti, Kampus IPB Dramaga, Bogor 16680, Indonesia Telp.\&Faks.62-251-8629353 e-mail agronipb@indo.net.id *Penulis untuk korespondensi: ilsacha@yahoo.com
\end{abstract}

Disetujui 24 Desember 2013/ Published Online 10 Januari 2014

\begin{abstract}
The quality of Tapeinochilos anannaceae K. Schum (kasturi) as cut flower must be kept on freshness during the storage, so it needs to get a good post harvest treatment. One of the post harvest technology can be applied is 1-Methylcyclopropene (1-MCP). The position of flower at the storage can also affect the vase life of cut flowers. This experiments is aimed leng then the vase life of kasturi cut flower by using 1-MCP, to get the optimum concentration of 1-MCP and to get the best storage position for prolonging the vase life of kasturi cut flower. The experiments was arranged in a randomized completely design with factorial pattern, consisted of two factors and ten replications. First factor was the concentration of 1-MCP, consisted of five levels: 0 ppm (AO), $0.1 \mathrm{ppm}$ (A1), $0.2 \mathrm{ppm}$ (A2), $0.3 \mathrm{ppm}$ (A3), and $0.4 \mathrm{ppm}$ (A4). The second factor was the storage in vertical and horizontal position. The results showed that application of 1-MCP can prolong the vase life of kasturi cut flower until 1.2-1.8 times compare without 1-MCP application. The combination of optimum treatment to extend vase life kasturi flowers cut is 1-MCP with 0.3 ppm concentration and stored in vertical position.
\end{abstract}

Key words: 1-Methylcyclopropene, kasturi, storage position, vase life

\section{ABSTRAK}

Kualitas bunga Tapeinochilos anannaceae K. Schum (kasturi) sebagai bunga potong harus dipertahankan kesegarannya selama masa simpan, sehingga perlu diaplikasikan perlakuan pasca panen yang tepat. Salah satu perlakuan pasca panen yang dapat digunakan adalah pemberian 1Methylcyclopropene (1-MCP). Posisi bunga selama penyimpanan diduga dapat mempengaruhi vase life bunga potong. Penelitian ini bertujuan untuk memperpanjang vase life bunga potong kasturi dengan menggunakan 1-MCP, mendapatkan konsentrasi 1-MCP optimum dan mencari posisi yang terbaik untuk memperpanjang vase life bunga potong kasturi. Penelitian ini menggunakan rancangan acak lengkap (RAL) faktorial yang terdiri dari dua faktor dan sepuluh ulangan, faktor pertama adalah konsentrasi 1-MCP yang terdiri dari lima taraf: 0 ppm (A0), 0.1 ppm (A1), 0.2 ppm (A2), 0.3 ppm (A3) dan 0.4 ppm (A4). Faktor kedua yaitu posisi penyimpanan secara vertikal dan horizontal. Hasil penelitian menunjukkan bahwa aplikasi 1-MCP pada bunga potong kasturi secara nyata dapat memperpanjang vase life bunga potong kasturi hingga 1.2-1.8 kali lipat dibandingkan tanpa perlakuan 1-MCP. Kombinasi perlakuan yang optimum untuk memperpanjang vase life bunga potong kasturi adalah 1-MCP dengan konsentrasi 0.3 ppm dan disimpan dengan posisi vertikal.

Kata kunci: 1-Methylcyclopropene, kasturi, posisi penyimpanan, vase life 


\section{PENDAHULUAN}

Berbagai jenis tanaman hias tropis sudah banyak yang dikembangkan secara komersial. Di antara tanaman hias tropika tersebut, terdapat beberapa jenis bunga potong tropika tumbuh dan berkembang baik di Indonesia. Kasturi merupakan salah satu bunga yang termasuk dalam famili Costaceae, bunga ini mampu beradaptasi dengan baik di iklim tropika. Sebenarnya yang disebut dengan bunga potong ini adalah susunan braktea atau seludang bunga. Indonesia sebagai negara tropika mempunyai potensi untuk mengembangkan bunga kasturi secara mudah dibandingkan dengan negara-negara beriklim subtropik. Negara yang beriklim subtropik membutuhkan teknologi dan biaya yang lebih mahal untuk mengembangkan bunga kasturi ini. Selain digemari oleh masyarakat Indonesia, bunga ini juga digemari oleh masyarakat negara maju dari kawasan subtropik seperti Amerika Serikat dan Jepang.

Kendala utama dalam pengembangan ekspor bunga potong adalah singkatnya kesegaran bunga karena kondisi genetik dan dipacu faktor lingkungan.Supaya bunga tetap segar dan menarik, maka perlu diaplikasikkan perlakuan pasca panen yang tepat.Salah satu teknologi pasca panen yang kini sudah mulai diterapkan di beberapa negara adalah penggunaan bahan kimia sebagai bahan pengawet berupa 1 Methylcyclopropene (1-MCP).1-MCP adalah suatu senyawa volatil turunan cyclopropene yaitu cyclic olefin yang memiliki kemampuan memblokir reseptor penangkap etilen sehingga mampu memperpanjang umur simpan dan mempertahankan kualitas produk hortikultura (Sisler dan Serek, 1997). Hasil penelitian yang dilakukan Chutichudet et al. (2010) menunujukkan bahwa vase life bunga Patumma (Curcuma alismatifolia) dapat diperpanjang dengan penggunaan 1-MCP pada konsentrasi 300 ppb atau $0.3 \mathrm{ppm}$ dengan aplikasi 1-MCP selama 8 jam. Hasil penelitian yang dilakukan Mubarok (2012) menunjukkan bahwa penggunaan volatile 1-MCP $0.2 \mu \mathrm{L} \mathrm{L}^{-1}$ atau $0.2 \mathrm{ppm}$ menunjukkan hasil terbaik dalam memperpanjang kesegaran bunga pelargonium pada semua kultivar.

Cara penyimpanan yang kurang tepat juga dapat mempersingkat masa simpan bunga potong. Menurut pedagang bunga potong kasturi di Rawa Belong pada saat di transportasikan bunga potong ini di posisikan secara horizontal dengan ujung yang bersilangan, sedangkan menurut Direktorat
Budidaya Tanaman Hias (2006) posisi bunga potong kasturi harus dalam posisi vertikal.

Berdasarkan permasalahan tersebut, tujuan penelitian adalah untuk memperpanjang vase life bunga potong kasturi dengan menggunakan 1MCP, mendapatkan konsentrasi 1-MCP optimum yang dapat memperpanjang vase life bunga potong kasturi dan mencari posisi yang terbaik untuk memperpanjang vase life bunga potong kasturi.

\section{BAHAN DAN METODE}

Penelitian ini dilaksanakan pada bulan November 2012 - Maret 2013. Bahan utama penelitian ini adalah bunga potong kasturi dari pasar Rawa Belong Jakarta. Kriteria bunga potong yang digunakan antara lain diameter braktea 8-10 $\mathrm{cm}$ berbentuk lingkaran, bagian bawah braktea datar dan panjang tangkai 50-60 cm, jumlah tumpukan braktea 4-6 tumpuk, jumlah braktea 3239. Bahan utama lain yang digunakan adalah 1 Methylcyclopropene (1-MCP) dan air. Alat yang digunakan yaitu box plastik, pisau, gelas plastik kecil, kotak karton, kipas angin kecil, adaptor, kabel, gelas ukur, perekat, mini color chart dari RHS (Royal Horticulture Society), timbangan digital dan analitik.

Penelitian ini menggunakan Rancangan Acak Lengkap (RAL) Faktorial dengan 2 faktor yaitu faktor pertama adalah konsentrasi 1-MCP yang terdiri dari lima taraf: $0 \mathrm{ppm}(\mathrm{A} 0), 0.1 \mathrm{ppm}$ (A1), $0.2 \mathrm{ppm}$ (A2), $0.3 \mathrm{ppm}$ (A3), dan $0.4 \mathrm{ppm}$ (A4). Faktor kedua yaitu posisi penyimpanan bunga potong terdiri dari posisi penyimpanan secara vertikal dan posisi penyimpanan secara horizontal. Data yang diperoleh dianalisis dengan menggunakan uji sidik ragam (uji F) pada taraf $5 \%$. Jika menunjukkan pengaruh yang nyata terhadap hasil pengamatan maka dilakukan analisis uji lanjut Duncan Multiple Range Test (DMRT) pada taraf nyata 5\%. Data diolah menggunakan SAS.

Tahap awal dari penelitian ini adalah survei bunga di pasar Rawa Belong. Selanjutnya bunga potong kasturi dibeli pada pagi hari untuk mencegah bunga mengalami stres dan dehidrasi berlebihan selama transportasi. Selang waktu dari panen bunga potong kastui hingga diberi perlakuan adalah 15 jam. Bunga dibungkus karton agar tidak rusak karena adanya pergesekan. Bunga yang telah dikemas selanjutnya dibawa ke Laboratorium Pasca Panen Departemen Agronomi dan Hortikultura IPB (lokasi penelitan) dengan menggunakan mobil yang tidak berpendingin. 
Setelah sampai di laboratorium dilakukan penyortiran dan peyeragaman berdasarkan kondisi keutuhan braktea, jumlah braktea, jumlah tumpukan braktea dan panjang tangkai.

Pada tahap pemaparan bunga potong kasturi dengan gas 1-MCP diawali dengan menghitung volume ruang yang digunakan sertamenghitung volume bunga potong kasturi yang akan terkena kontak 1-MCP dengan cara menghitung volume air yang tumpah pada box plastik yang telah diisi air yang penuh sampai permukaan atas lalu dicelupkan bunga potong kasturi. Serbuk1-MCP ditimbang sesuai dengan konsentrasi gas yang akan dipaparkan dengan menggunakan timbangan digital. Cara menghitung besarnya serbuk 1-MCP yang diberikan :

$\mathrm{x}=\underline{\text { konsentrasi yang diharapkan } \mathrm{x} \text { volume bebas }}$ bahan aktif yang terkandung

1-MCP dilarutkan dengan air (ratio 4:1 terhadap bobot 1-MCP). Bunga potong kasturi dan botol yang berisi larutan 1-MCP tadi, dalam 1 box berisi 10 tangkai bunga potong kasturi dimasukkan ke dalam box. Gelas plastik kecil ditempatkan di tengah box dan diatas gelas tersebut ditempatkan kipas angin (fan) untuk mensirkulasi gas. Pada saat terjadi kontak antara air dengan serbuk 1-MCP, box segera ditutup rapat dengan bantuan perekat kemudian disimpan di suhu kamar selama 8 jam. Setelah diaplikasi 1-MCP, bunga disimpan sesuai dengan perlakuan yaitu dengan posisi horizontal dan vertikal. Perlakuan horizontal ditempatkan di kotak karton dengan posisi dengan ujung yang bersilangan sedangkan untuk posisi vertikal ditempatkan di kotak karton dengan posisi bunga di atas.Peubah yang diamati antara lain warna braktea, warna tangkai, susut bobot, bunga biologis, uji hedonik dan vase life(masa pajang).

\section{HASIL DAN PEMBAHASAN}

\section{Kondisi Bunga Kasturi}

Penelitian ini menggunakan bahan percobaan berupa bunga potong kasturi. Kriteria bunga yang digunakan antara lain diameter braktea $8-10 \mathrm{~cm}$ berbentuk lingkaran, bagian bawah braktea datar, jumlah tumpukan braktea 46 tumpuk, jumlah braktea 32-39, kondisi braktea segar, berwarna merah, dengan tangkai berwarna kuning kecoklatan, panjang tangkai $55-60 \mathrm{~cm}$ diukur dari ujung tangkai sampai pangkal braktea, dan mempunyai bunga asli dengan jumlah 9-11 yang sebagian besar masih kuncup. Bunga kasturi yang digunakan termasuk kelas medium, berdasarkan klasifikasi panjang tangkai yaitu berukuran $50-80 \mathrm{~cm}$.

Bunga potong kasturi diperoleh dari pasar bunga Rawa Belong. Bunga yang sudah dibeli lalu dikemas dalam kardus dengan posisi horizontal dan kardus tersebut diikat dengan tali rafia. Bunga potong tersebut dibawa ke Laboratorium Pasca Panen (tempat penelitian) menggunakan mobil tanpa pendingin. Selang waktu dari panen bunga potong kastui hingga diberi perlakuan adalah 15 jam. Salah satu hal yang harus diperhatikan adalah waktu dari panen ke pengaplikasian 1-MCP. Pengaplikasian 1-MCP harus segera dilakukan pada komoditas yang baru dipanen (Blankenship dan Dole 2003).

\section{Warna Braktea}

Warna braktea bunga kasturi ini tidak mengalami perubahan secara signifikan selama masa penyimpanan, hal tersebut didapatkan dari pengukuran warna braktea bunga kasturi dengan menggunakan mini color chart dari RHS. Braktea bunga kasturi berwarna merah, sesuai dengan kode warna Red RHS 45 A. Hal yang membedakan warna braktea sebelum dan setelah diberi perlakuan sebenarnya adalah adanya warna semburat hitam braktea, semburat hitam ini muncul dari tepi kemudian ke dalam braktea. Semakin panjang vase life maka waktu munculnya braktea yang menghitam semakin lambat.

Kondisi braktea yang menghitam tersebut dijadikan sebagai parameter vase life dari bunga ini karena semakin banyak semburat hitam pada braktea maka penampakannya semakin tidak menarik. Satu helai braktea dikatakan sudah menghitam dan dapat dijadikan untuk parameter vase life apabila $70 \%$ dari satu helai sudah menghitam. Parameter tersebut digunakan berdasarkan uji hedonik dimana para panelis masih menyukai kondisi helaian braktea yang menghitam kurang dari $70 \%$.

Data pada Tabel 1 menunjukkan adanya interaksi yang nyata antara konsentrasi 1-MCP dengan posisi penyimpanan terhadap jumlah braktea menghitam pada 3 hari setelah perlakuan (HSP), 6 HSP dan 7 HSP. Perlakuan konsentrasi berpengaruh nyata terhadap jumlah braktea menghitam pada 1 HSP hingga 4 HSP, 6 HSP dan 7 HSP. Konsentrasi 0.4 ppm menghasilkan jumlah braktea yang menghitam paling sedikit pada 1 HSP hingga 7 HSP. Posisi penyimpanan 
berpengaruh nyata terhadap jumlah braktea yang menghitam pada 1 HSP dan 3 HSP. Posisi vertikal menghasilkan jumlah braktea menghitam paling sedikit dibandingkan dengan posisi horizontal.

Bunga potong yang tidak diberi perlakuan 1-MCP memiliki vase lifeyang hanya mencapai 5 HSP pada kondisi dimana 30\% dari jumlah keseluruhan braktea menjadi hitam, sedangkan kondisi yang sama pada bunga potong yang diberi 1-MCP dapat mencapai 6 HSP hingga 9 HSP (Tabel 2). Hasil uji lanjut pada Tabel 2 menunjukkan pada 3 HSP jumlah braktea menghitam pada kombinasi perlakuan 1-MCP dengan konsentrasi $0.3 \mathrm{ppm}$ vertikal serta $0.4 \mathrm{ppm}$ horizontal dan vertikal pada bunga potong kasturi berbeda nyata dengan perlakuan lainnya. Perlakuan kombinasi 1-MCP dengan konsentrasi $0.3 \mathrm{ppm}$ vertikal dan $0.4 \mathrm{ppm}$ horizontal pada 6 HSP berbeda nyata dengan perlakuan yang lainnya kecuali dengan perlakuan $0.4 \mathrm{ppm}$ secara vertikal. Perlakuan kombinasi $0.3 \mathrm{ppm}$ vertikal pada 7 HSPberbeda nyata dengan perlakuan kombinasi yang lainnya kecuali dengan perlakuan $0.4 \mathrm{ppm}$ horizontal dan vertikal. Waktu munculnya jumlah braktea menghitam paling lambat terjadi pada kombinasi perlakuan 1-MCP dengan konsentrasi $0.3 \mathrm{ppm}$ secara vertikal.

Selain pengaruh 1-MCP dalam laju respirasi, menurut Blankenship dan Dole (2003) 1-MCP juga dapat memperlambat degradasi klorofil dan protein. 1-MCP sendiri dapat mencegah dan memperlambat jenis perubahan warna yang terjadi pada beberapa bagian tanaman.

Bunga potong kasturi yang diaplikasikkan 1-MCP waktu menghitamnya braktea lebih lambat dibandingkan yang tidak diberi perlakuan 1-MCP. Hal yang serupa terjadi pada hasil penelitian Feng et al. (2000) dimana 1-MCP dapat memperlambat perubahan warna kulit alpukat.

\section{Warna Tangkai}

Warna tangkai pada bunga potong kasturi merupakan salah satu ukuran kesegaran secara visual.Pengukuran perubahan warna tangkai pada bunga potong kasturi menggunakan mini color chart dari RHS (Royal Horticulture Society). Warna tangkai yang dimaksud berupa warna selaput yang melapisi tangkai bunga ini. Sebelum diberikan perlakuan hampir semua tangkai berwarna kuning kecoklatan namun selama pengamatan berlangsung semua tangkai mengalami perubahan warna menjadi lebih gelap seperti warna orange kecoklatan, merah kecoklatan, coklat, ungu tua kemerahan dan ungu kecoklatan. Perubahan warna tersebut dijadikan sebagai salah satu kriteria dalam penampakan bunga.

Data pada Tabel 3 jumlah tangkai yang berwarna ungu kecoklatan pada bunga yang tidak diberi perlakuan 1-MCP 50\% secara horizontal dan $80 \%$ secara vertikal, sedangkan bunga potong yang diberi perlakuan 1-MCP paling banyak hanya $50 \%$. Secara umum pada 5 HSP yang tidak diaplikasikkan 1-MCP jumlah tangkai yang berwarna ungu kecoklatan lebih banyak dibandingkan dengan yang diaplikasikan 1-MCP. Hal ini menunjukkan bahwa perubahan warna tangkai yang terjadi pada bunga potong kasturi yang tidak diaplikasikan 1-MCP menjadi gelap lebih cepat dibandingkan dengan yang diaplikasikkan 1-MCP karena warna ungu kecoklatan merupakan warna yang paling tua dalam perubahan warna tangkai pada penelitian ini.

Tabel 1. Jumlah braktea menghitam pada berbagai konsentrasi dan posisi penyimpanan

\begin{tabular}{lccccccccc}
\hline \multirow{2}{*}{ Perlakuan } & \multicolumn{8}{c}{ Jumlah braktea menghitam (helai) } \\
\cline { 2 - 10 } & 1 HSP & 2 HSP & 3 HSP & 4 HSP & 5 HSP & 6 HSP & 7 HSP & 8 HSP & 9 HSP \\
\hline Konsentrasi & & & & & & & & & \\
$0 \mathrm{ppm}$ & $3.92 \mathrm{c}$ & $4.85 \mathrm{c}$ & $6.35 \mathrm{c}$ & $8.57 \mathrm{~b}$ & $10.07 \mathrm{a}$ & & & & \\
$0.1 \mathrm{ppm}$ & $3.64 \mathrm{c}$ & $4.64 \mathrm{c}$ & $6.50 \mathrm{c}$ & $7.71 \mathrm{~b}$ & $8.71 \mathrm{a}$ & $10.28 \mathrm{~b}$ & $10.71 \mathrm{ab}$ & & \\
$0.2 \mathrm{ppm}$ & $4.57 \mathrm{c}$ & $5.00 \mathrm{c}$ & $5.92 \mathrm{c}$ & $7.92 \mathrm{~b}$ & $10.28 \mathrm{a}$ & $11.50 \mathrm{~b}$ & $13.20 \mathrm{~b}$ & & \\
$0.3 \mathrm{ppm}$ & $2.50 \mathrm{~b}$ & $3.28 \mathrm{~b}$ & $4.28 \mathrm{~b}$ & $5.57 \mathrm{a}$ & $6.64 \mathrm{a}$ & $8.14 \mathrm{a}$ & $9.57 \mathrm{a}$ & 9.71 & 10.00 \\
$0.4 \mathrm{ppm}$ & $0.92 \mathrm{a}$ & $2.00 \mathrm{a}$ & $2.78 \mathrm{a}$ & $4.42 \mathrm{a}$ & $5.57 \mathrm{a}$ & $6.78 \mathrm{a}$ & $8.07 \mathrm{a}$ & 10.07 & \\
Posisi penyimpanan & & & & & & & & \\
Horizontal & $3.47 \mathrm{~b}$ & 4.25 & $5.62 \mathrm{~b}$ & 6.97 & 7.82 & 9.28 & 9.85 & 11.03 & \\
Vertikal & $2.77 \mathrm{a}$ & 3.65 & $4.71 \mathrm{a}$ & 6.71 & 9.07 & 9.52 & 9.92 & 10.00 & 11.4 \\
\hline Interaksi & $\mathrm{tn}$ & $\mathrm{tn}$ & $*$ & $\mathrm{tn}$ & $\mathrm{tn}$ & $*$ & $*$ & tn & tn \\
\hline
\end{tabular}

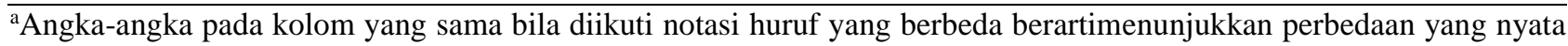
pada selang kepercayaan $95 \%$. 
Tabel 2. Pengaruh kombinasi aplikasi 1-MCP dan posisi penyimpanan terhadap jumlah braktea menghitam

\begin{tabular}{|c|c|c|c|c|c|c|c|c|c|c|c|c|c|c|c|c|c|c|}
\hline \multirow{3}{*}{ Perlakuan } & \multicolumn{18}{|c|}{ 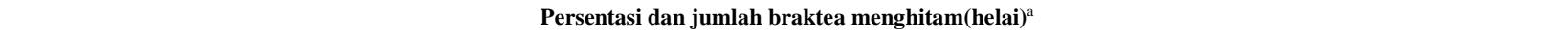 } \\
\hline & \multicolumn{2}{|c|}{1 HSP } & \multicolumn{2}{|c|}{2 HSP } & \multicolumn{2}{|c|}{3 HSP } & \multicolumn{2}{|c|}{4 HSP } & \multicolumn{2}{|c|}{5 HSP } & \multicolumn{2}{|c|}{$6 \mathrm{HSP}$} & \multicolumn{2}{|c|}{7 HSP } & \multicolumn{2}{|c|}{8 HSP } & \multicolumn{2}{|c|}{9 HSP } \\
\hline & $\%$ & $\sum$ & $\%$ & $\sum$ & $\%$ & $\sum$ & $\%$ & $\sum$ & $\%$ & $\sum$ & $\%$ & $\sum$ & $\%$ & $\sum$ & $\%$ & $\sum$ & $\%$ & $\sum$ \\
\hline $0 \mathrm{ppm} \mathrm{H}$ & 10.7 & 4.86 & 11.84 & 5.38 & 16.43 & $7.43 \mathrm{c}$ & 19.91 & 9.00 & 30.02 & 13.57 & - & - & - & - & - & - & - & - \\
\hline $0 \mathrm{ppm} \mathrm{V}$ & 9.30 & 3.00 & 13.73 & 4.43 & 20.80 & $6.71 b c$ & 26.07 & 8.14 & 37.51 & 11.71 & - & - & - & - & - & - & - & - \\
\hline $0.1 \mathrm{ppm} \mathrm{H}$ & 9.80 & 3.57 & 11.78 & 4.29 & 15.29 & $5.57 b c$ & 20.01 & 7.29 & 21.58 & 7.86 & 25.89 & $9.43 b c$ & 32.15 & $11.71 \mathrm{bc}$ & - & - & - & - \\
\hline $0.1 \mathrm{ppm} \mathrm{V}$ & 9.40 & 3.71 & 12.67 & 5.00 & 16.65 & $6.57 b c$ & 20.62 & 8.14 & 24.60 & 9.71 & 30.66 & $12.00 \mathrm{c}$ & - & - & - & - & - & - \\
\hline $0.2 \mathrm{ppm} \mathrm{H}$ & 14.10 & 4.29 & 15.48 & 4.71 & 18.31 & $5.57 b c$ & 23.96 & 7.29 & 24.42 & 8.43 & 28.97 & $10.00 \mathrm{c}$ & 38.06 & $13.14 \mathrm{c}$ & - & - & - & - \\
\hline $0.2 \mathrm{ppm} \mathrm{V}$ & 12.80 & 4.57 & 14.82 & 5.29 & 17.62 & $6.29 \mathrm{bc}$ & 24.00 & 8.57 & 26.02 & 7.71 & 30.00 & $10.71 \mathrm{c}$ & 37.22 & $13.29 \mathrm{c}$ & - & - & - & - \\
\hline $0.3 \mathrm{ppm} \mathrm{H}$ & 10.80 & 3.29 & 14.54 & 4.43 & 18.74 & $5.71 \mathrm{bc}$ & 22.52 & 6.86 & 22.68 & 7.71 & 29.42 & $10.00 \mathrm{c}$ & 36.16 & $12.29 \mathrm{c}$ & - & - & - & - \\
\hline $0.3 \mathrm{ppm} \mathrm{V}$ & 5.90 & 1.71 & 7.38 & 2.14 & 9.87 & $2.86 a$ & 14.80 & 4.29 & 19.22 & 5.57 & 22.19 & $6.43 a$ & 24.64 & $7.14 \mathrm{a}$ & 29.57 & 8.57 & 34.50 & 10.00 \\
\hline $0.4 \mathrm{ppm} \mathrm{H}$ & 8.30 & 1.43 & 9.11 & 1.57 & 10.14 & $2.86 \mathrm{a}$ & 14.18 & 4.00 & 18.23 & 5.14 & 21.27 & $6.00 \mathrm{a}$ & 27.34 & $7.71 \mathrm{ab}$ & 31.91 & 9.00 & - & - \\
\hline $0.4 \mathrm{ppm} \mathrm{V}$ & 3.10 & 0.86 & 5.15 & 1.43 & 9.26 & $2.57 \mathrm{a}$ & 15.97 & 4.43 & 20.58 & 5.71 & 25.23 & $7.00 \mathrm{ab}$ & 29.34 & $8.14 \mathrm{ab}$ & 37.09 & 10.29 & - & - \\
\hline
\end{tabular}

${ }^{\text {a} A n g k a-a n g k a ~ p a d a ~ k o l o m ~ y a n g ~ s a m a ~ b i l a ~ d i i k u t i ~ n o t a s i ~ h u r u f ~ y a n g ~ b e r b e d a ~ b e r a r t i ~ m e n u n j u k k a n ~ p e r b e d a a n ~ y a n g ~ n y a t a ~}$ pada selang kepercayaan 95\%; H: penyimpanan secara horizontal. V: penyimpanan secara vertikal.

Tabel 3. Pengaruh kombinasi aplikasi 1-MCP dan posisi penyimpanan terhadap warna tangkai bunga potong kasturi $5 \mathrm{HSP}$

\begin{tabular}{ccccccc}
\hline & \multicolumn{7}{c}{ 5 HSP } \\
\cline { 2 - 6 } Perlakuan & \multicolumn{7}{c}{ Warna tangkai bunga (\%) } \\
\cline { 2 - 6 } & $\begin{array}{c}\text { Kuning } \\
\text { kecoklatan }\end{array}$ & $\begin{array}{c}\text { Orange } \\
\text { kecoklatan }\end{array}$ & $\begin{array}{c}\text { Merah } \\
\text { kecoklatan }\end{array}$ & Coklat & $\begin{array}{c}\text { Ungu tua } \\
\text { kemerahan }\end{array}$ & $\begin{array}{c}\text { Ungu } \\
\text { kecoklatan }\end{array}$ \\
\hline 1-MCP 0 ppm H & 0 & 0 & 20 & 0 & 30 & 50 \\
1-MCP 0 ppm V & 10 & 0 & 10 & 0 & 0 & 80 \\
1-MCP 0.1 ppm H & 0 & 0 & 20 & 0 & 50 & 30 \\
1-MCP 0.1 ppm V & 0 & 0 & 30 & 0 & 20 & 50 \\
1-MCP 0.2 ppm H & 0 & 20 & 0 & 0 & 30 & 50 \\
1-MCP 0.2 ppm V & 0 & 10 & 40 & 0 & 30 & 20 \\
1-MCP 0.3 ppm H & 20 & 30 & 0 & 0 & 10 & 40 \\
1-MCP 0.3 ppm V & 30 & 20 & 30 & 0 & 20 & 0 \\
1-MCP 0.4 ppm H & 20 & 10 & 0 & 10 & 40 & 20 \\
1-MCP 0.4 ppm V & 30 & 10 & 0 & 0 & 30 & 30 \\
\hline
\end{tabular}

${ }^{\mathrm{a}} \mathrm{H}$ : penyimpanan secara horizontal, V: penyimpanan secara vertikal.

\section{Susut Bobot}

Selama pengamatan berlangsung bunga potong kasturi mengalami susut bobot.Data pada Tabel 4 menunjukkan adanya interaksi yang nyata antara konsentrasi 1-MCP dengan posisi penyimpanan terhadap susut bobot bunga potong kasturi pada 5 HSP. Perlakuan konsentrasi berpengaruh nyata terhadap susut bobot pada 2 HSP, 5 HSP dan 6 HSP. Perlakuan tanpa 1-MCP menghasilkan susut bobot tertinggi pada 1 HSP hingga 3 HSP, sedangkan perlakuan 1-MCP dengan konsentrasi $0.4 \mathrm{ppm}$ menghasilkan susut bobot tertinggi pada 4 HSP hingga 8 HSP. Hasil uji lanjut pada Tabel 5 menunjukkan bahwa kombinasi perlakuan 1-MCP dengan konsentrasi $0.1 \mathrm{ppm}, 0.2 \mathrm{ppm}$ dan $0.3 \mathrm{ppm}$ secara horizontal pada 5 HSP berbeda nyata dengan perlakuan kombinasi $0.3 \mathrm{ppm}$ vertikal, $0.4 \mathrm{ppm}$ vertikal dan horizontal.

Menurut Santoso (2012) bunga potong akan mengalami kehilangan air setelah panen khususnya pada saat penyimpanan. Etilen merupakan hormon yang memiliki rumus kimia $\mathrm{C}_{2} \mathrm{H}_{4}$ ini berpengaruh terhadap proses respirasi. Produksi etilen erat hubungannya dengan laju respirasi karena etilen dapat memacu untuk menyerap oksigen lebih banyak.

Tetap berlangsungnya proses respirasi selama waktu penyimpanan menurut Kader (1992) akan mengubah senyawa-senyawa kompleks yang berada di dalam sel seperti gula $\left(\mathrm{C}_{6} \mathrm{H}_{12} \mathrm{O}_{6}\right)$ menjadi senyawa-senyawa sederhana seperti karbondioksida $\left(\mathrm{CO}_{2}\right)$ dan air $\left(\mathrm{H}_{2} \mathrm{O}\right)$ kemudian mengalami penguapan (transpirasi) sehingga terjadi susut bobot.

Pada penelitian ini 1-MCP tidak berpengaruh besar dalam parameter susut bobot karena secara umum bunga potong kasturi yang diaplikasikan 1-MCP mengalami susut bobot yang lebih besar dibandingkan dengan yang tidak diberi perlakuan 1-MCP. Namun kesegaran tidak hanya dilihat dari susut bobotnya saja sehingga pengukuran vase life juga harus berdasarkan 
parameter lainnya yang dapat dilihat secara visual. Kondisi bunga kasturi selama pengamatan berlangsung yang terkait dengan kehilangan air atau susut bobot ini tidak berpengaruh terhadap penampilan bunga ini secara umum seperti layu atau patah karena bunga ini mempunyai keragaan yang kokoh. Perubahan yang terjadi dengan adanya susut bobot ini hanya saja bekas potongan tangkai terlihat lebih berongga.

Tabel 4. Susut bobot bunga potong kasturi pada berbagai konsentrasi 1-MCP dan posisi penyimpanan

\begin{tabular}{|c|c|c|c|c|c|c|c|c|c|}
\hline \multirow{2}{*}{ Perlakuan $^{a}$} & \multicolumn{9}{|c|}{ Susut bobot $(\%)^{\mathrm{a}}$} \\
\hline & 1 HSP & 2 HSP & 3 HSP & 4 HSP & 5 HSP & 6 HSP & 7 HSP & 8 HSP & 9 HSP \\
\hline \multicolumn{10}{|l|}{ Konsentrasi } \\
\hline $0 \mathrm{ppm}$ & $4.00 \mathrm{~b}$ & $7.28 \mathrm{~d}$ & 10.85 & 14.42 & $16.84 \mathrm{a}$ & & & & \\
\hline $0.1 \mathrm{ppm}$ & $2.20 \mathrm{a}$ & $6.05 b c$ & 9.69 & 12.90 & $15.32 \mathrm{a}$ & $19.46 \mathrm{a}$ & & & \\
\hline $0.2 \mathrm{ppm}$ & $2.50 \mathrm{a}$ & $6.23 \mathrm{~cd}$ & 10.09 & 13.75 & $16.01 \mathrm{a}$ & $21.74 \mathrm{~b}$ & & & \\
\hline $0.3 \mathrm{ppm}$ & $3.00 \mathrm{a}$ & $5.71 \mathrm{a}$ & 9.56 & 13.27 & $16.12 \mathrm{ab}$ & $18.62 \mathrm{a}$ & 21.54 & 24.68 & 27.53 \\
\hline $0.4 \mathrm{ppm}$ & $3.00 \mathrm{a}$ & $6.10 \mathrm{a}$ & 10.52 & 14.93 & $18.64 \mathrm{ab}$ & $22.85 \mathrm{c}$ & 24.85 & 26.99 & \\
\hline \multicolumn{10}{|c|}{ Posisi penyimpanan } \\
\hline Horizontal & 2.90 & 6.26 & 10.12 & 13.59 & 16.03 & 20.32 & 22.53 & 25.24 & \\
\hline Vertikal & 2.90 & 6.24 & 10.12 & 13.97 & 16.99 & 20.99 & 23.70 & 26.55 & 29.4 \\
\hline
\end{tabular}

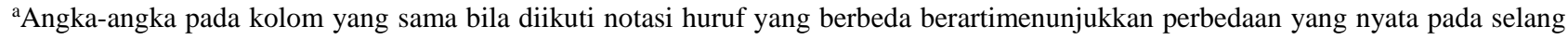
kepercayaan $95 \%$.

Tabel 5. Pengaruh kombinasi aplikasi 1-MCP dan posisi penyimpanan terhadap susut bobot bunga potong kasturi

\begin{tabular}{|c|c|c|c|c|c|c|c|c|c|}
\hline \multirow[b]{2}{*}{ Perlakuan } & \multicolumn{9}{|c|}{ Susut bobot $(\%)^{\mathrm{a}}$} \\
\hline & $\begin{array}{c}1 \\
\text { HSP }\end{array}$ & $\begin{array}{c}2 \\
\text { HSP }\end{array}$ & $\begin{array}{c}3 \\
\text { HSP }\end{array}$ & $\begin{array}{c}4 \\
\text { HSP }\end{array}$ & $\begin{array}{c}5 \\
\text { HSP }\end{array}$ & $\begin{array}{c}6 \\
\text { HSP }\end{array}$ & $\begin{array}{c}7 \\
\text { HSP }\end{array}$ & $\begin{array}{c}8 \\
\text { HSP }\end{array}$ & $\begin{array}{c}9 \\
\text { HSP }\end{array}$ \\
\hline Pemaparan 1-MCP 0 ppm horizontal & 3.95 & 7.36 & 10.72 & 14.20 & $16.85 \mathrm{ab}$ & - & - & - & - \\
\hline Pemaparan 1-MCP 0 ppm vertikal & 3.87 & 7.42 & 10.54 & 14.19 & $16.39 \mathrm{ab}$ & - & - & - & - \\
\hline $\begin{array}{l}\text { Pemaparan 1-MCP } 0.1 \mathrm{ppm} \\
\text { horizontal }\end{array}$ & 2.89 & 6.53 & 9.94 & 13.00 & $15.44 \mathrm{a}$ & 19.87 & - & - & - \\
\hline Pemaparan 1-MCP 0.1 ppm vertikal & 2.86 & 7.34 & 11.17 & 14.27 & $17.26 \mathrm{ab}$ & - & - & - & - \\
\hline $\begin{array}{l}\text { Pemaparan 1-MCP } 0.2 \mathrm{ppm} \\
\text { horizontal }\end{array}$ & 1.92 & 5.56 & 9.24 & 12.88 & $14.74 \mathrm{a}$ & 20.21 & - & - & - \\
\hline Pemaparan 1-MCP 0.2 ppm vertikal & 3.30 & 6.82 & 10.51 & 14.35 & $16.63 \mathrm{ab}$ & 23.57 & - & - & - \\
\hline $\begin{array}{l}\text { Pemaparan 1-MCP } 0.3 \mathrm{ppm} \\
\text { horizontal }\end{array}$ & 4.06 & 7.09 & 10.31 & 14.01 & $15.71 \mathrm{a}$ & 18.21 & 20.78 & - & - \\
\hline Pemaparan 1-MCP 0.3 ppm vertikal & 2.75 & 2.58 & 9.92 & 14.47 & $18.69 \mathrm{cb}$ & 21.51 & 24.22 & 26.68 & 29.75 \\
\hline $\begin{array}{l}\text { Pemaparan 1-MCP } 0.4 \text { ppm } \\
\text { horizontal }\end{array}$ & 3.18 & 6.42 & 10.94 & 14.70 & $18.84 \mathrm{cb}$ & 24.36 & 25.12 & 28.41 & - \\
\hline Pemaparan 1-MCP 0.4 ppm vertikal & 2.96 & 5.90 & 11.03 & 15.17 & $19.24 \mathrm{cb}$ & 23.13 & 25.61 & 29.41 & - \\
\hline
\end{tabular}

${ }^{a}$ Angka-angka pada kolom yang sama bila diikuti notasi huruf yang berbeda berarti menunjukkan perbedaan yang nyata pada selang kepercayaan $95 \%$.

\section{Bunga Biologis}

Bunga dikatakan bunga lengkap apabila mempunyai empat bagian sebagai berikut yaitu kelopak (calyx), tajuk ataumahkota (corolla), benang sari (stamen) dan putik (pistillum). Bunga kasturi termasuk bunga lengkap, karena memiliki keempat bagian tersebut. Bunga biologis kasturi ini terdapat pada hampir setiap helaian braktea. Warna kelopak bunga, putik dan benang sari adalah putih serta mahkota berwarna kuning. Sebelum diberi perlakuan hampir semua bunga biologis berwarna kuning ini masih kuncup, jumlah bunga biologis yang ada dalam satu tangkai sebelum perlakuan adalah 9-11 bunga.

Data pada Tabel 6 menunjukkan adanya interaksi yang nyata antara konsentrasi 1-MCP dengan posisi penyimpanan terhadap umur bunga. Konsentrasi 1-MCP berpengaruh nyata terhadap umur bunga. Perlakuan 1-MCP dengan konsentrasi $0.4 \mathrm{ppm}$ menghasilkan umur bunga paling lama dibandingkan dengan konsentrasi lainnya. Posisi penyimpanan tidak berpengaruh nyata terhadap umur bunga dan posisi 
penyimpanan vertikal menghasilkan umur bunga paling lama dibandingkan dengan posisi horizontal. Hasil uji lanjut pada Tabel 7 menunjukkan bahwa perlakuan kombinasi 0.3 ppm secara vertikal, $0.4 \mathrm{ppm}$ secara horizontal dan vertikal berbeda nyata dengan perlakuan kombinasi lainnya.

Tabel 6. Umur bunga pada berbagai konsentrasi 1-MCP dan posisi penyimpanan

\begin{tabular}{lc}
\hline Perlakuan & Umurbunga (hari) $^{\mathrm{a}}$ \\
\hline Konsentrasi & \\
$0 \mathrm{ppm}$ & $2.14 \mathrm{bc}$ \\
$0.1 \mathrm{ppm}$ & $2.64 \mathrm{bc}$ \\
$0.2 \mathrm{ppm}$ & $1.71 \mathrm{c}$ \\
$0.3 \mathrm{ppm}$ & $3.92 \mathrm{ab}$ \\
$0.4 \mathrm{ppm}$ & $4.78 \mathrm{a}$ \\
Posisi penyimpanan & \\
Horizontal & 2.71 \\
Vertikal & 3.37 \\
\hline Interaksi & $*$
\end{tabular}

${ }^{2}$ Angka-angka pada kolom yang sama bila diikuti notasi huruf yang berbeda berarti menunjukkan perbedaanyang nyata pada selang kepercayaan $95 \%$.

Proses kelayuan atau dalam hal ini gugur merupakan tahapan yang normal yang selalu terjadi dalam siklus kehidupan tanaman,akan tetapi proses kelayuan dapat dipercepat dengan adanya air atau karbohidrat yang hilang dan penurunan bobot akibat terjadi kebocoran ion (Courts, 1973). Peningkatan kelayuan juga dipengaruhi oleh adanya etilen. Bunga yang memiliki vase life yang lebih lama diduga bunga tersebut memiliki kemampuan memproduksi etilen yang rendah dalam proses metabolismenya. Produksi etilen dimulai pada waktu terjadinya peningkatan respirasi dan kelayuan atau gugur terjadi tidak lama setelah adanya peningkatan respirasi. Semakin rendah laju respirasi, produksi etilen juga semakin rendah. Pada kondisi ini reseptor etilen menangkap 1-MCP sehingga etilen yang tidak tertangkap akan hilang dan laju respirasi pun akan berkurang. Penurunan laju respirasi mengakibatkan proses kelayuan akan terhambat.

Melihat hasil yang ada secara umum umur bunga dari kuncup hingga gugur yang diaplikasikkan 1-MCP lebih lama dibandingkan yang tidak diberi perlakuan 1-MCP membuktikan bahwa 1-MCP mampu berpengaruh nyata terhadap umur bunga dari kuncup hingga gugur. 1-MCP mampu menghambat penangkapan etilen oleh reseptor yang dapat menyebabkan penurunan laju respirasi dan memperlambat gugurnya bunga sehingga lamanya bunga mekar menjadi lebih panjang.

Tabel 7. Pengaruh kombinasi aplikasi 1-MCP dan posisi penyimpanan terhadap umur bunga kasturi dari kuncup hingga gugur

\begin{tabular}{|c|c|}
\hline Perlakuan & $\begin{array}{l}\text { Umur bunga } \\
\text { (hari) }^{\mathrm{a}}\end{array}$ \\
\hline $\begin{array}{l}\text { Pemaparan 1-MCP } 0 \text { ppm } \\
\text { horizontal }\end{array}$ & $2.29 b c$ \\
\hline $\begin{array}{l}\text { Pemaparan 1-MCP } 0 \text { ppm } \\
\text { vertikal }\end{array}$ & $2.00 \mathrm{bc}$ \\
\hline $\begin{array}{l}\text { Pemaparan 1-MCP } 0.1 \text { ppm } \\
\text { horizontal }\end{array}$ & $2.57 b c$ \\
\hline $\begin{array}{l}\text { Pemaparan 1-MCP } 0.1 \text { ppm } \\
\text { vertikal }\end{array}$ & $2.71 b c$ \\
\hline $\begin{array}{l}\text { Pemaparan 1-MCP } 0.2 \text { ppm } \\
\text { horizontal }\end{array}$ & $1.43 \mathrm{c}$ \\
\hline $\begin{array}{l}\text { Pemaparan 1-MCP } 0.2 \text { ppm } \\
\text { vertikal }\end{array}$ & $2.00 \mathrm{bc}$ \\
\hline $\begin{array}{l}\text { Pemaparan 1-MCP } 0.3 \text { ppm } \\
\text { horizontal }\end{array}$ & $2.00 \mathrm{bc}$ \\
\hline $\begin{array}{l}\text { Pemaparan 1-MCP } 0.3 \text { ppm } \\
\text { vertikal }\end{array}$ & $5.86 a$ \\
\hline $\begin{array}{l}\text { Pemaparan 1-MCP } 0.4 \text { ppm } \\
\text { horizontal }\end{array}$ & $5.29 a$ \\
\hline $\begin{array}{l}\text { Pemaparan 1-MCP } 0.4 \text { ppm } \\
\text { vertikal }\end{array}$ & $4.29 \mathrm{a}$ \\
\hline
\end{tabular}

\section{Uji Hedonik}

Uji hedonik adalah uji kesukaan dimana panelis diminta tanggapan kesukaan atau kebalikannya. Uji hedonik dipercobaan dilakukan oleh tiga orang panelis.dimana penilaiannya berdasarkan penampakan bunga potong kasturi berupa warna braktea dan tangkai. Warna braktea pada hari ke-0 sampai vase life dari masingmasing perlakuan berakhir tidak mengalami perubahan yang signifikan sehingga panelis menilai dari banyaknya braktea yang menghitam, sedangkan untuk warna tangkai sendiri ada beberapa tangkai yang mengalami perubahan.

Nilai hedonik yang digunakan berskala 1 sampai 5. Nilai 1 menunjukkan panelis sangat tidak suka, nilai 2 menunjukkan panelis tidak suka, nilai 3 menujukan panelis biasa saja/netral, nilai 4 menunjukkan panelis suka, dan nilai 5 menunjukkan panelis sangat suka terhadap penampakan bunga kasturi. Apabila nilai uji hedonik berada di atas 3.0 maka bunga kasturi masih dapat diterima oleh konsumen dan apabila nilai uji hedonik berada di bawah 3.0 maka bunga 
kasturi sudah tidak dapat diterima lagi oleh konsumen. Uji hedonik berhenti apabila vase lifenya habis yaitu ketika 30\% dari keseluruhan braktea menghitam.

Secara umum konsumen menyukai penampakan bunga potong kasturi ini pada 4 HSP, dimana pada 6 perlakuan yang diaplikasikkan pada bunga potong kasturi masih dapat diterima oleh panelis yaitu pemaparan 1-MCP dengan konsentrasi $0.1 \mathrm{ppm}$ secara horizontal, 1-MCP dengan konsentrasi $0.2 \mathrm{ppm}$ secara vertikal, 1MCP dengan konsentrasi $0.3 \mathrm{ppm}$ dan $0.4 \mathrm{ppm}$ secara horizontal dan vertikal (Gambar 1). Vase life pada perlakuan dengan konsentrasi $0.3 \mathrm{ppm}$ vertikal adalah 9 HSP namun uji hedonik berhenti pada 8 HSP karena uji hedonik ini dilakukan dua hari sekali. Hal tersebut menunjukkan bahwa penampakan dari bunga kasturi dengan perlakuan 1-MCP pada konsentrasi $0.3 \mathrm{ppm}$ secara vertikal masih cukup menarik sehingga masih bisa diterima oleh panelis. Melihat uji hedonik ini dapat diketahui bahwa panelis lebih tertarik dengan warna braktea yang merah dengan tidak ada atau sedikit semburat hitam dan warna tangkai yang berwarna kuning kecoklatan. Semakin tua warna tangkai maka kesegarannya semakin menurun sehingga tidak menarik lagi.

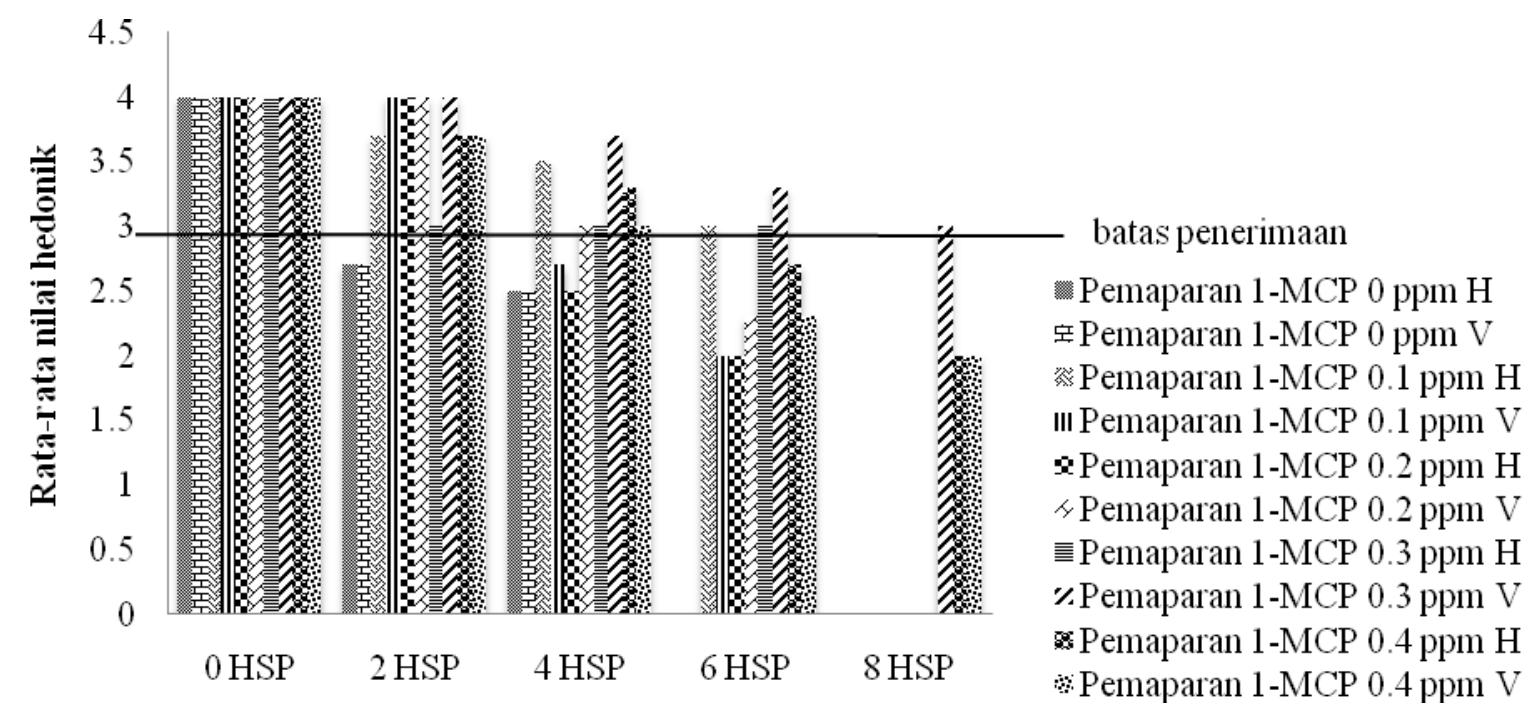

Gambar 1. Pengaruh 1-MCP dan posisi penyimpanan terhadap nilai hedonik kesukaanbunga kasturi. Huruf $\mathrm{H}$ menunjukkan penyimpanan secara horizontal dan huruf $\mathrm{V}$ menunjukkan penyimpanan secara vertikal

\section{Vase life}

Vase life bunga potong merupakan lamanya umur relatif bunga potong dalam keadaan tetap segar dan indah setelah dipotong dari tanaman induknya (Wiryanto, 1993). Perubahan 30\% dari kesuluruhan braktea menghitam merupakan parameter yang digunakan untuk memperhitungkan vase life.

Data pada Tabel 8 menunjukkan adanya interaksi yang nyata antara konsentrasi 1-MCP dengan posisi penyimpanan terhadap vase life bunga potong kasturi. Perlakuan konsentrasi berpengaruh nyata terhadap vase lifebunga potong kasturi. 1-MCP dengan konsentrasi 0.3 ppm menghasilkan vase life yang paling lama dibandingkan dengan konsentrasi lainnya. Perlakuan posisi penyimpanan sendiri tidak berpengaruh nyata terhadap vase life bunga potong kasturi. Hasil uji lanjut pada Tabel 9 menunjukkan bahwa perlakuan kombinasi 1-MCP $0.3 \mathrm{ppm}$ secara vertikal lebih lama vase lifenya dibandingkan dengan semua perlakuan kombinasi lainnya kecuali dengan perlakuan 0.4 ppm secara vertikal.

Menurut Setyadjit et al. (2012) mekanisme aksi senyawa 1-MCP dalam menghambat kematangan, mencegah pengaruh buruk etilen, serta menghambat senesens adalah dengan memblokir reseptor etilen yang ada pada tanaman sehingga etilen tidak dapat menempati reseptor tersebut. Agar terlihat adanya gejala dari pengaruh etilen, senyawa etilen harus menempel pada suatu reseptor ligand yang berupa asam lemak yang kemudian akan memberi sinyal untuk terjadi suatu efek fisiologis. Senyawa 1-MCP menempati reseptor tersebut secara permanen sehingga etilen tidak dapat terikat lagi setelah 1-MCP telah terikat pada suatu reseptor. 1-MCP yang menyebabkan etilen tersebut menurukan laju respirasi. 
Penurunan laju respirasi sendiri dapat berpengaruh pada vase life bunga potong, semakin menurun laju respirasinya maka vase lifenya semakin lama.

Tabel 8. Pengaruh aplikasi 1-MCP dan posisi penyimpananterhadap vase lifebunga potong kasturi

\begin{tabular}{lc}
\hline Perlakuan & ${\text { Vase life }(\text { HSP })^{\mathrm{a}}}$ \\
\hline Konsentrasi & \\
$0 \mathrm{ppm}$ & $4.83 \mathrm{c}$ \\
$0.1 \mathrm{ppm}$ & $6.16 \mathrm{~b}$ \\
$0.2 \mathrm{ppm}$ & $6.50 \mathrm{~b}$ \\
$0.3 \mathrm{ppm}$ & $7.83 \mathrm{a}$ \\
$0.4 \mathrm{ppm}$ & $7.66 \mathrm{a}$ \\
Posisi penyimpanan & \\
Horizontal & 6.60 \\
Vertikal & 6.60 \\
\hline Interaksi & $*$
\end{tabular}

Interaksi

angka-angka pada kolom yang sama bila diikuti notasihuruf yang berbeda berarti menunjukkan perbedaan yang nyata pada selang kepercayaan $95 \%$.

Tabel 9. Pengaruh kombinasi aplikasi 1-MCP dan posisi penyimpanan terhadap vase life bunga potong kasturi

\begin{tabular}{lc}
\hline Perlakuan & $\begin{array}{c}\text { Vase life } \\
\text { (HSP) }^{\mathrm{a}}\end{array}$ \\
\hline Pemaparan 1-MCP 0 ppm horizontal & $5.0 \mathrm{e}$ \\
Pemaparan 1-MCP 0 ppm vertikal & $4.7 \mathrm{e}$ \\
Pemaparan 1-MCP 0.1 ppm & $7.0 \mathrm{~cd}$ \\
horizontal & $5.7 \mathrm{e}$ \\
Pemaparan 1-MCP 0.1 ppm vertikal & $6.7 \mathrm{~cd}$ \\
Pemaparan 1-MCP 0.2 ppm & $6.3 \mathrm{~d}$ \\
horizontal & $7.0 \mathrm{~cd}$ \\
Pemaparan 1-MCP 0.2 ppm vertikal & Pemaparan 1-MCP 0.3 ppm \\
horizontal & $8.7 \mathrm{a}$ \\
Pemaparan 1-MCP 0.3 ppm vertikal & $7.3 \mathrm{bc}$ \\
Pemaparan 1-MCP 0.4 ppm & horizontal \\
Pemaparan 1-MCP 0.4 ppm vertikal & $8.0 \mathrm{ab}$ \\
\hline
\end{tabular}

${ }^{a}$ Angka-angka pada kolom yang sama bila diikuti notasi huruf yangberbeda berarti menunjukkan perbedaan yang nyata pada selang kepercayaan $95 \%$.

Posisi vertikal sendiri memberikan pengaruh pada umur vase life karena dengan posisi tersebut susunan braktea lebih sedikit mengalami benturan dengan braktea yang lainnya maupun dengan kardus sehingga kerusakan yang terjadi seperti patahnya braktea tidak ada, walaupun ada tetapi lebih kecil dibandingkan dengan posisi horizontal. Selain itu penyimpanan dalam posisi tegak bertujuan agar bunga tidak melengkung ke bawah yang diakibatkan oleh geotropisme. Hal ini sesuai dengan peraturan dari Direktorat Budidaya Tanaman Hias (2006) dimana pengemasan harus dalam posisi berdiri.

Vase life untuk bunga potong kasturi menurut Direktorat Budidaya Tanaman Hias (2006) adalah 10 hari, namun menurut pedagang bunga potong kasturi di Rawa Belong, bunga ini hanya tahan 4 hari tanpa pengawet. Adanya perbedaan tersebut disebabkan karena pasca panen yang dilakukan oleh pedagang hanya sebatas dicelupkan ke air saja, sedangkan berdasarkan Direktorat Budidaya Tanaman Hias perlakuan pasca panen yang dilakukan pada bunga potong kasturi ini antara lain disimpan pada suhu $7-10^{\circ} \mathrm{C}$ dengan kelembaban 90-95\% tidak lebih dari 5 haridan dilakukan dengan merendam tangkai bunga dalam air serta menghindari penyimpanan kering.

Hasil yang didapat bahwa dengan perlakuan 1-MCP mampu memperpanjang vase lifebunga potong kasturi 1.2 hingga 1.8 kali lipat. Perlakuan kombinasi terbaik terdapat pada perlakuan 1-MCP dengan konsentrasi $0.3 \mathrm{ppm}$ dengan posisi vertikal karena menghasilkan vase life yang paling lama yaitu 8.7 hari. Hal ini membuktikan bahwa bunga potong kasturi merupakan salah satu tanaman yang sensitif etilen, dengan adanya etilen tersebut muncul beberapa pengaruh yang dapat mempengaruhi vase life bunga ini. Pada penelitian ini penangkapan etilen oleh reseptor dihambat dengan adanya 1-MCP sehingga dapat meminimalisir pengaruh buruk akibat adanya etilen terhadap vase life bunga potong kasturi.

\section{KESIMPULAN}

Perlakuan 1-MCP secara nyata mampu memperpanjang vase life bunga potong kasturi hingga 8.7 hari dibandingkan dengan tanpa perlakuan 1-MCP yaitu hanya 4.7 hari. Kombinasi perlakuan yang optimum untuk memperpanjang vase life bunga potong kasturi hingga 8.7 hari adalah 1-MCP dengan konsentrasi $0.3 \mathrm{ppm}$ dan disimpan dalam posisi vertikal. Pengukuran vase life tersebut berdasarkan parameter $30 \%$ dari total braktea menghitam dan $70 \%$ dari satu helai braktea menghitam. 


\section{DAFTAR PUSTAKA}

Blankenship SM, Dole JM. 2003. 1Methylcyclopropane: a review. Postharvest Biol. Technol. 28: 1 - 25.

Chutichudet $\mathrm{P}$, Chutichudet B, Boontiang K. 2010. Effect of 1-MCP on vase life and other postharvest qualities of patumma (Curcuma alismatifolia)cv. Chiang Mai Pink. Trends in Horticultural Research.1: $1-11$.

[Ditflorikultura] Direktorat Budidaya Tanaman Hias. 2006. Standar Prosedur Operasional Tapeinochilus ananassae [Internet]. [diunduh 2012 November 4]. Tersedia pada florikultura.org/pedum/SOP_Tapeinochilus _ananassae.pdf

Feng X, Apelbaum A, Sisler EC, Goren R. 2000. Control of ethylene respones in avocado fruit with 1-methylcyclropropene. Postharvest Biol Technol 20:143-150.

Kader AA. 1992. Postharvest Technology of Horticulture Crops. California (US):
University of California Division of Agriculture and Natural Resources.

Mubarok S. 2012. 1-Methylcyclopropene (1$\mathrm{MCP}$ ) untuk memperpanjangkesegaran bunga pada tiga kultivar bunga pelargonium zonale hybrids [Internet]. [diunduh 2012 November 7]. Tersedia pada: http://balithi.litbang.deptan.go.id.

Santoso BB. 2012. Penyimpanan komoditi hortikultura [Internet]. [diunduh2013 April 17]. Tersedia pada: http://fp.unram.ac.id

Setyadjit, Sukasih E, Permana AW. 2012. Aplikasi 1-MCP dapat memperpanjang umur segar komoditas hortikultura. Bul. Teknologi Pascapanen Pertanian. Vol 8(1): 28-29.

Sisler EC, Serek M. 1997. Inhibitors of ethylene responses in planta at the receptor level: recent developments. Physiol Plant. 100:577-582.

Wiryanto K. 1993. Penanganan pasca panen bunga anggrek. Buletin Anggrek. 06: 20. 